\title{
On Ongoing Conflict: Lessons From Afghanistan (1978-1989)*
}

\author{
Sergey Ratz \\ Saint-Petersburg State University, Saint-Petersburg, Russia
}

\begin{abstract}
The ethnic conflict, the Civil War, Soviet-Afghan War, and international military operations in Afghanistan in the end of the 20th century have profound impacts on the development of various mechanisms: (1) to regulate international armed conflicts in the global political arena; (2) to reach consensus; and (3) to establish peace and rules of justice that must be recognized by all international institutions. This paper aims to consider essential issues related to Soviet military units participated in the political conflict in Afghanistan and a role of the competition for dominant position between the key-players, the Union of Soviet Socialist Republics (USSR), and the USA, in 1979-1989. Consideration of the Soviet and American operations and political activities of Afghan opposition during that turbulent decade in the international politics puts forward the lesson learned analysis, which should prevent us from repeating errors and lead us to international cooperation and high-level dialogs among countries, which are dealing with the regional and global security problems, and to focus on preventing violence, instability, unexpected accidents, and armed intervention.
\end{abstract}

Keywords: conflict, war, invasion, politics, strategy

\section{Introduction}

\section{The Basics}

In the history of the land and a state, which is Afghanistan nowadays, many countries had important national political and economic interests. It is a well-known fact in the Afghan history that the Alexander the Great, Genghis Khan, and the Mongol Army made a number of endeavors to control this "crossroads of Central Asia". The Great Britain many times announced how important this country of Central Asia for the economic system and three times attempted to take a total control over the Afghan territory (Savinkin \& Snesarev, 2003, p. 40). For the Russian Empire, this territory had a special strategic interest: Afghanistan was located at the southern border of Russia. In 1919, Afghanistan was a first country that officially recognized the independence of the new Soviet state. In 1921, the Treaty of Friendship and Military cooperation was signed by the Union of Soviet Socialist Republics (USSR) and Afghanistan. During the two decades (1956-1978), Afghanistan received $\$ 1.26$ billion with the economic assistance from the Soviet Union, and the cost of military aid was \$1.25 billion. Compare to the United States, only \$533 million was provided to Afghanistan in the 1950s, later the US administration lost interest in this region (Rashid, 2003, p. 31). In the 1970s, the USSR invested $\$ 2.5$ billion in the development of the economy of Afghanistan, five times more than the United States. By the

\footnotetext{
* Acknowledgement: The author of this article accumulated the main points of the paper that was delivered at the 47th Annual Convention of Association for Slavic, East European \& Eurasian Studies in November 2015 in Philadelphia, PA. The author sincerely thanks Dr. Linna Liberchuk for suggestions and professional language help in preparing this paper for publication.

Sergey Ratz, Ph.D, associate professor, Faculty of the Institute of Philosophy, Saint-Petersburg State University, Saint-Petersburg, Russia.
} 
mid-1970s, Soviet geologists discovered unique deposits of oil for Central Asia (0.4 billion barrels), gas (3.5 billion cubic meters), copper, coal, iron ore, gold, silver, aluminum, emerald, deposits of cobalt, and lithium.

In the late 1970s, more than 6,000 Soviet specialists were employed as contractors in the northern provinces at manufacturing plants of Afghanistan. In 1984, the Afghan Republic, partially compensating for the military and economic assistance of the USSR, supplied 4 million cubic meters of natural gas to the republics of Soviet Central Asia. That is $90 \%$ of all gas produced by Afghanistan for the specified period. In fact, we acknowledge with great confidence that the subject of the geopolitical confrontation between the USSR and the USA in the 1970s was the bowels of Afghanistan and its advantageous strategic position (Rashid, 2003, p. 199). The economic and political priorities in this region were important until April 1978, when the overthrow of an existing government by a group of officers, Marxist admirers, trained in Crimea on the basis of the (UT-165) Training and Terrorism Center was carried out (Malevany, 2009, p. 95). Later, the Soviet researchers called this event "the April revolution".

\section{Turbulent Decade}

The decade from 1979 to 1989 was the most controversial in relations with the southern neighbor. By the spring of the 1980s, Afghanistan had become a major issue in the cold war between the United States and the USSR, and the mujahideen troops fought against Soviet and Democratic Republic of Afghanistan (DRA) military units. The Soviet Army was drawn into a grueling civil war. The fact that the Soviet 40th Army invaded the territory of a sovereign state gave impetus to the consolidation of all anti-Soviet forces that were led by the United States and the Great Britain. The "New Great Game" in Central Asia and a competition among world powers for influence in Afghanistan has continued (Ratz, 2015).

In Afghanistan, the population was divided into several camps. The tribal leaders initiated a movement of resistance using reforms regarding distribution of water and land resources which have been problems since ancient times. The government leaders were cut off from the masses and did not take into account peculiarities of tribal relations and the influence of Muslim spiritual leaders on the illiterate population. The leadership of the Democratic Republic of Afghanistan (DRA) faced a massive desertion in the army. For instance: On March 15, 1979 in Herat, citizens incited by the mullahs revolted against the central government. The local troops stationed in the town fought on the side of the Mujahideen. Spiritual and tribal leaders declared jihad. At that time, nine months before the entry of Soviet troops into Afghanistan, Soviet specialists were identified with the leaders of the People's Democratic Party of Afghanistan (PDPA).

The word "shuravi" (an older, respected Soviet brother) instantly became a symbol of the enemy of the Afghan people. In just a few of hours in Herat, a crowd of fanatics killed dozens of military advisers, specialists, and their families. Ahmed Rashid, a Pakistani international journalist and author of the book on Taliban, describes this day:

While residents killed Soviet officers, advisers, and their families, Ismail Khan staged a coup in the local garrison, killing Soviet officers and Afghan communists, armed the people. Ismail Khan took refuge in the countryside, leading the partisan army, and tens of thousands of civilians fled to Iran. (2003, p. 58)

Hundreds of thousands of refugees came to Pakistan and Iran. Here, the secret services of North Atlantic Treaty Organization (NATO), Pakistan, Iran, and China deployed hundreds of camps for training the mujahideen. According to Yutov (2003), dushmans received a special training in 124 training centers in 
Pakistan and in 18 locations in Iran: In Pakistan, 10 former generals, 40 colonels, and 100 officers of lower rank were trained by mujahideen. In turn, in the Soviet Union, various schools, institutes, and universities taught and trained up to 50,000 Afghan students and specialists every year (p. 11).

The difficulties came to a head in 1979 when anti-government protests took place in big cities, such as Herat, Nuristan, and Baluchistan: Each day, the protestors paralyzed the government, and jihad had received a great support. In this situation, the PDPA leaders repeatedly asked the Politburo of the Communist Party for military assistance. It is a well-known fact that the decision to bring troops into Afghanistan was not made immediately. The members of Politburo, experienced politicians, L. I. Brezhnev, A. A. Gromyko, D. F. Ustinov, and $\mathrm{Yu}$. V. Andropov, carefully analysed the risks of such an operation, but they could not fully predict a scale of the future catastrophe. A successful strategist, chief of the General Staff of the Soviet Ministry of Defense, Marshal N. V. Ogarkov, was against military involvement in Afghanistan. He warned the colleagues about disastrous consequences of this plan and a negative resonance of the world community; also, he predicted civilian and military casualties, depletion of resources, and increase of financial expenses. Nevertheless, a point of view of Yu. Andropov, a head of the Komitet Gosudarstvennoi Bezopasnosti (KGB), prevailed upon a common sense. He informed all authorities that he received materials on activities of Western security forces in this region in order to weaken the influence of the Soviet Union in this geopolitical space. What was so attractive for the Soviet leaders in Afghanistan that could force them to make such a fateful and tragic decision? What was the subject of conflict? (Ratz, 2015).

There is a legend that L. I. Brezhnev seriously endured the news regarding the murder of N. Taraki by the Amin's henchmen. After that, allegedly the General Secretary gave an order to Yu. V. Andropov to storm the palace of Taj Beg and to eliminate H. Amin. In the author's opinion, the decision to deploy troops in Afghanistan was made as a result of information received by the KGB officers in Kabul. According to the intelligence report, the Central Intelligence Agency (CIA) was preparing an operation for the regime changing in Afghanistan. Therefore, American radars and medium-range missiles could appear at the southern border of the USSR. However, the determining factor was the danger and fear of the Soviet leadership to lose Afghanistan, in which significant monetary investments were made for the economic development of the country, e.g., in the north of Afghanistan in the Mazar-i-Sharif region, the plant for manufacturing nitrogen fertilizers operated effectively. Secondly, according to Soviet geologists, in the northern regions, oil, gas, and uranium deposits were discovered. The gas pipeline carrying gas from Afghanistan replenished the energy intensity of the republics in Central Asia. Additionally, important factors were: (1) a growing movement of Wahhabism and (2) the need to defend the southern borders from the penetration of drugs into the USSR, as well as to protect in Afghanistan about 5,000 Soviet specialists who came to the country during the civil war. For the leaders of the Communist Party, Afghanistan seemed to be like a "figure" in chess, which was not possible to lose in this "New Great Game", despite all damages and losses (not very substantial, as they argued) that could not be visible in 1979. After the invasion of the Soviet troops, the situation was dramatically changed.

\section{Some Historical Facts}

On December 24, 1979, the 40th Soviet Army, approximately 40,000 troops (125 troops during the Soviet-Afghan War), crossed the border of Afghanistan in three locations: Kushka-Kandahar, Termez-Kunduz-Kabul, and Khorog-Faizabad. On December 27, 1979, a coup was carried out by the KGB and 
Afghan units loyal to the PDPA. The troops occupied main government facilities, including the Taj Beck Palace. During the assault, the leader of the PDPA and a head of state Hafizullah Amin together with his guards (almost 200 people) were killed. Babrak Karmal, a nominee of the Soviet leadership, became a head of state and the PDPA leader. In this attack, five special security officers, five soldiers of the "Muslim battalion", and one of the leaders a leader of Operation Storm-333, Colonel Grigory Boyarinov were killed (the posthumously award of "Hero of the Soviet Union" was given to his family). On December 28, at two o'clock in the morning, the Kabul radio broadcasted a speech of Babrak Karmal, a new leader of the country. It was assumed that the 40th Army would occupy the strategic points of Afghanistan and deploy the garrisons, but not participate in a growing civil war. However, in the second half of January in 1980, following an urgent request of Karmal, the Soviet paratroopers intervened in the operation to suppress the insurgency. To understand the situation, we have to consider the issues of this war before the war began: Military officials of the Soviet 40th Army and top Soviet scholars, who had courage to tell the truth to power, attempted to prevent the Soviet-Afghan war.

In May 1980, D. F. Ustinov, marshal and minister of defense, on behalf of high ranking military leaders (Army General M. Mayorov, Lieutenant-General V. Samoilenko, and Lieutenant-General V. Cheremnykh), wrote a letter in which he provided an analysis and prospects of the political situation in Afghanistan. Officials (unanimously) supported a main point: the continued presence of Soviet troops in Afghanistan could lead to unpredictable consequences.

On August 1, 1980, the government DRA (Democratic Republic of Afghanistan) controlled only 47\% of districts (134 counties out of the 286) where hostilities affected the process of organization of local administration. On May 1, the DRA government controls already 184 districts (64\%), vital areas of the country. However, in most of the counties and townships controlled by the government, insurgency massive support was growing. Also, we believe that in this difficult military-political situation in Afghanistan at this time and in the future, it is extremely difficult to solve the task of defeating counterrevolution and establish people's democratic power in the whole country only by military efforts of the 40th Army and DRA military is unrealistic. (Cheremnykh, 1995, p. 275)

In January 1980, a group of academicians inspired by O. Bogomolov wrote a letter to L. I. Brezhnev. The scholars noted that

the confrontation on two fronts, against NATO in Europe and against China in East Asia, could add the third dangerous hotbed of military-political problems near the southern outskirts of the USSR, in unfavorable geographical location and a fact that we have to deal with the combined resources of the United States and other NATO countries, China, Muslim states, the rebel armies of the Afghans and Afghanistan can become the Vietnam of Moscow. (Savinkin \& Snesarev, 2003, p. 735)

Additionally, A. Mareichev, major and adviser in Afghanistan, addressed his note to Yu. Andropov. In his note, A. Mareichev described the situation in the Afghan Army, enourmous unreasonable attacks against the citizens of the republic. He wrote about unfavorable developments of events in the future and mentioned the possible growth of the insurgent movement. He understood that his letter did not have much of an impact on decision making regarding deployment troops in Afghanistan: "I believe that my call to Moscow did not bring the expected results" (Chekisty of Leningrad in Afganistan, 2009, p. 15). Nevertheless, it should be noted that there is no written evidence of responses from the Communist Party leadership to the letters of concern on their country "wrong track". 


\begin{abstract}
Afghan National Army
The Afghan Army performed a key function in the war. The army (from 180 to 200 thousand troops) was equipped with modern Soviet technology. The officer corps recruited pashtuns who were trained in the USSR. The promotion to leadership was based only on a party membership and a group an officer belonged to "Parcham" or "Khalk". The law on universal military duty of 1980 pushed many tribes away from the central government that were historically free from mobilization, e.g., Khorezmians lived in inaccessible mountains, Baluchis migrated seasonally. In 1980, the army was staffed by $60 \%$ units of the Ministry of Internal Affairs and $32 \%$ facts of desertion and theft of weapons, switching to the side of the mujahideen became regular (Cheremnykh, 1995, p. 281).

Further, a vital role in the creation of security forces and its structure (hierarchy) belonged to the Soviet KGB officials: They adopted a system of Committee of State Security of the Soviet Union. The security units aimed to obtain preliminary data regarding mujahideen activities, terrorist plans, and those fighters who were hide in underground. In 1980, the State Information Service (HAD) was established in each province. Depending on special operational tasks, dozens of different nationalities operatives worked in provinces. Many of security personnel spoke Russian: Their chiefs were advisers or employees of the KGB, who worked as contractors in Afghanistan. A. Mareichev told:

Together with Colonel Abdul Haq Samadi, who served as a head of the military counterintelligence of the Afghan Army, the deployment position and structure of the security forces in the DRA troops were established. The unit location was approved by Amin Hafizullah. In a short time, leaders and operational officers, about a hundred people, were selected for the Afghan military counterintelligence divisions being formed by the Afghan Army, with whom I had to spend monthly training sessions. In early 1979, the first group of Soviet military counterintelligence arrived in Afghanistan. Between 1978 and 1979, Afghan officers under the leadership of our advisers detected and exposed more than twenty agents of bandit groups assigned to destroy the troops, two Pakistani intelligence agents, and eleven cases of anti-government protests were prevented. (Cheremnykh, 1995, p. 13)
\end{abstract}

N. M. Kalugin, a retired colonel and former employee of the KGB office in Kabul, provided the following assessment of the Afghan economy in 1983: Territory controlled by gangs of the armed opposition. For this reason, to meet the needs of the national economy, oil and gas pipelines were extended from the USSR border to Kabul, which required especially reliable protection and the use of all available forces and means. For this purpose, advisors to the central office and territorial offices of the Ministry of State Security of Afghanistan developed and implemented a corresponding set of measures that allowed them to protect as a shield these vital arteries from hostile attacks of the enemy (Yutov, 2003, p. 226). A group of Soviet advisers worked in Afghanistan until the end of 1991: They helped to prevent the penetration of the mujahideen's agents in the territory of the Soviet republics of in Central Asia and to suppress terrorist attacks.

\title{
The End of the Soviet-Afghan War
}

After the withdrawal of the Soviet Army, the PDPA regime existed for three years, and in 1992, was defeated. One of the reasons for the defeat of the DRA government was the cessation of economic and military assistance from Russia. Former Soviet Ambassador to Kabul N. G. Egorychev in his book on Soviet assistance to Afghanistan in 1990 noted:

After the start of Gorbachev's leapfrog in the economy, this became too heavy a burden for our country. Aid to Afghanistan cost us every year 10 billion foreign currency rubles. In dollars it is even more 15-16 billion. We received 
telegrams weekly: let Najibullah know that his request for the supply of this and that on credit for ten years was granted. Of course, no one was going to return these loans. This price has become exorbitant for us. (Kommersant, 2002, pp. 77-78)

Industrial facilities built primarily with the Soviet assistance were mostly destroyed, or became unusable, and irrigation systems were destroyed. Opium poppy was the only crop that farmers grew in order not to die of hunger. During 10 years of the civil war in Afghanistan, the USSR casualty were: 15,000 soldiers and officers, more than 500 state security officers, among them 15 KGB officers, and more than 45,000 troops wounded. The Soviet foreign policy failed in Afghanistan, the Soviet people suffered heavy moral damage, and the economy unable to withstand 10 years of work for the war, pushed the USSR to collapse and complete political bankruptcy. Ahmed Rashid, a well-known expert on the problems of Central Asia, provided a following assessment of the USSR role in the war:

For Afghans, the Soviet invasion was just another attempt by foreigners to subdue them and replace the time-tested religion and society with someone else's ideology and social structure. Jihad inflamed with new force as the United States, China and the Arab countries gave more and more money and weapons to the Mujahideen. This war, which claimed the lives of 1.5 million Afghans, will spawn a second generation of Mujahideen, who will call themselves Taliban, or "students who are studying Islam". (2003, p. 32)

\section{Lessons from Afghanistan: Considerations and Implications}

What lessons can be learned from the analysis of the events and conflicting international activities in this region during a decade of tension, from the end of 1979 to the end of 1989? (Ratz, 2015). First, the intervention of the USSR and the USA in the internal affairs of a sovereign state led to grave political consequences-a civil war in the region and a humanitarian catastrophe. In the chaos of civil war, more than 1.5 million Afghans died. The humanitarian disaster affected millions of Afghans. Neighboring countries Pakistan and Iran have struggled to find common ground on controversial issues related to refugees, their widespread frustration and hostility. In fact, the USSR contributed to establishment of an anti-Soviet Muslim coalition by countries, such as Saudi Arabia, Pakistan, Iran, Egypt, and the Soviet Union, after 10 years of support of the Afghan Army turned out to meet political and economic isolation from the West and China.

Secondly, the invasion of the Soviet 40th Army into the territory of Afghanistan gave impetus to the intensification of the opposition, the creation of insurgent groups under the "flag of Islam". In December 27, 1979, special KGB officers and members of the Soviet "Muslim battalion" carried out a coup d'état. The storm of the palace spawned a number of protests, involving Islam supporters. The consequences of this military operation had to be thought out deeper and more far-sighted. The military and KGB special groups and specialists implemented a unique intelligence and counterintelligence system in Afghanistan, besides they trained the 200th Army and several special force corps. The $90 \%$ of pashtuns were commanders in the Afghan Army, a few years later many of them joined the Taliban troops.

Thirdly, moral, psychological, and religious factors were not taken into account in full. In a country with almost total illiteracy, Islamic beliefs were values for their minds of citizens. The physical elimination of thousands of religious authorities by representatives of the secret services of the PDPA gave a new impetus to the strengthening of the opposition and the withdrawal of entire tribes to Pakistan. The civil war spawned the mujahideen's movement, the Taliban, the formation of al-Qaida groups which prepared a ground for the establishment of an aggressive Muslim state, the Islamic State of Iraq and Syria (ISIS).

Fourthly, the USSR in the struggle against the anti-Soviet coalition led by the United States, invested 
enormous financial and military resources (estimated $\$ 15$ billion during 1988) (Savinkin \& Snesarev, 2003, p. 729). Political leaders of the Communist party and the Soviet government did not respond to the letters signed in 1981 by a group of senior military leaders and scientists of the Soviet Union, which recommended immediately withdrawing the 40th Army from Afghanistan. The voices of the professionals were not heard. Unfortunately, only in 1986, the first six regiments left the country: This action did not significantly change the situation, and the civil war only expanded in that region.

Fifthly, an inaccuracy of information led to crucial political mistakes made by leaders of the Soviet government on December 8, 1979 at the Kremlin meeting. Yu. Andropov and D. Ustinov in the report for the Politburo justified the entry of a limited contingent of Soviet troops in Afghanistan, believing that the United States will be able to deploy the coalition troops in December 1979 or in January 1980. Thus, "Pershing" missiles could appear in the north of Afghanistan, a region theoretically could be "covered" by the Baikanur missile and space complex from strategic facilities. In addition, Americans could get and enrich uranium in northern Afghanistan, and break balance of the nuclear arms of the two superpowers. No one discussed in detail the political consequences of such a large-scale military action: The leadership, L. Brezhnev, Yu. Andropov, and D. Ustinov, wanted to see socialism in Afghanistan and realized a Russian idea to get access to the Indian Ocean.

Lastly, the Soviet political and military advisers tried to adapt communism based on ideological set of concepts in the country where the medieval tribalism had dominated. This proposal dissolved and led to establishment of a new antinational regime of the PDPA. The Soviet troops, 125,000 people of the 40th Army, represented a different civilization, culture, and values, invaded lives of the people who were in the cradle of humanity. As a result, the new government was not accepted by ordinary citizens and religious leaders. The new government endeavor to build up an Islamic republic in 1986 did not establish a positive working relationship with those they governed. Finally, it should be also noted the positive sides of the presence of the USSR in Afghanistan: The Soviet specialists built hydroelectric power stations, hospitals, schools, and the institutes of higher learning education for the young Afghan people. Also, the Soviets announced the fight against drugs. However, the civil war completely destroyed a whole infrastructure of the country. Despite the positive contribution made by the Russian specialists in order to develop economic, social, and educational institutions, the problems are stronger than they were when the Soviets attacked mujahideens. The only the image of the "shuravi", a Soviet Russian person, associated with a good, white giant with a gun in his hands remained in the memory of many Afghans presently. As a result of the fight for this region, the Soviet Union's politics and economic conditions were significantly damaged, the multinational Soviet community suffered with a humiliating reality, which combined with other factors, eventually prompted the collapse of the USSR.

\section{Conclusion}

In accordance with the 1921 Treaty between the Soviet and Afghan peoples, the USSR until 1991 provided military and economic assistance to Afghanistan. Various factions of the mujahideen came to power in 1992 and later in 1996 the Taliban took control in the country and good-neighborly relations were interrupted. The Taliban, proclaiming orthodox Islam, plunged the country into an even bloodier civil war, splitting Afghanistan into two irreconcilable camps along ethnic and religious lines: Pashtuns and other nationalities, on the one side, and Sunnis and Shiites, on the other side.

The Northern Alliance of Afghanistan with the support of Russia, India, Iran, Uzbekistan, Tajikistan, and 
Kyrgyzstan (Turkmenistan retained neutrality) actively opposed the Taliban movement. On January 19, 2000, the UN Security Council passed Resolution No. 1333, imposing sanctions only against the Taliban and banning the supply of weapons to the Taliban.

After an air attack on the World Trade Center in New York by al Qaeda suicide bombers on September 11, 2001, the United States launched a large-scale operation to destroy the center of world terrorism in Afghanistan. In January 2002, the first detachments of the International Assistance Force from 15 countries led by the United States and the Great Britain arrived in Kabul.

The world community tried to find a way to resolve the conflict. Despite the increase in the grouping of rapid response corps, the number of units of fighters for the faith grew every day. Al-Qaida perpetrators continue to commit acts of terrorism, and an endless stream of heroin is moving from the territory of Afghanistan to other countries. The experience of the USSR was not considered by the politicians of the NATO countries. Today, the "cargo 200" (a military code word referring the transportation of corpses of soldiers) is transporting zinc-lined coffins from Afghanistan to the countries of Western Europe and the United States. Unfortunately, after more than twenty years of civil war, ten years of struggle of the Afghan people for their independence, and 17 years of stay of the US Army in the country, the conflict region remains the "Gordian knot" of Central Asia and a hotbed of terrorism and drug epidemics. The strategic position of the country and its resources do not cease to be the subject of contradictory relations between the United States and China. As an object of geopolitical interests, Afghanistan remains at the center of major international problems for world powers: Both the US and Russia are exploring opportunities and considering proposals for resolving this international conflict at conferences and symposia from historical and contemporary perspectives. For example, online discussions and conferences on Afghanistan in Moscow and Qatar (Rashid, 2 February 2010, http://www.bbc.co.uk, August 28, http://www.nybooks.com; http://www.cic.nue.edu, http://www.cfr.org). How the fundamental ethnic and social problems will be solved and how statehood and political stability will develop in the republic will depend on the goodwill of the world community. It is necessary to consider the best cases from previous experiences of joint actions with the United States of America and reevaluate successful approaches in the fight against terrorism.

\section{References}

Chekisty of Leningrad in Afghanistan. (2009). Center of translation. Klint: Saint-Petersburg.

Cheremnykh, V. P. (1995). Not on Moscow's scenario. Klint: Saint-Petersburg.

Kommersant. (2002). Afghanistan cost us $\$ 15$ bln a year. Vlast, 46, 77-78.

Malevany, V. V. (2009). Soviet special security forces in Afghanistan. Moscow: Kuchkovo Pole.

Rashid, A. (2003). Taliban: Islam, oil and the new great game in Central Asia. Biblion: Russian Book.

Rashid, A. (2010). How to end the war in Afghanistan. Retrieved from http://bbc.uk.co/news

Ratz, S. (2015). Afghanistan as the object of the conflict between the USSR and the USA: 1979-1989. The 47th ASEEES Annual Convention, November 19-22, Philadelphia, PA.

Ratz, S. V. (2009). Leningrad's chekists in Afghanistan. Saint-Petersburg: Center for Translation.

Savinkin, A. E., \& Snesarev, A. E. (2003). Afghan lessons. Moscow: Russian Way.

Yutov, V. I. (2003). Kaskad \& Omega. Moscow: X-History. 